\title{
ANALISIS PENGETAHUAN CALON GURU KIMIA TENTANG PERALATAN LABORATORIUM DAN FUNGSINYA
}

\author{
Wirda Udaibah \\ Tadris Kimia Fakultas Ilmu Tarbiyah dan Keguruan \\ IAIN Walisongo Semarang
}

\begin{abstract}
Abstrak
Pembelajaran IPA berkaitan erat dengan cara mencari tahu (inkuiri) tentang alam semesta secara sistematis, sehingga IPA bukan hanya penguasaan pengetahuan berupa fakta, konsep atau prinsip saja, tetapi merupakan suatu proses penemuan. Hal tersebut diperoleh melalui kegiatan praktikum. Namun, pelaksanaannya di lapangan memiliki beberapa kelemahan antara lain rendahnya pengetahuan guru tentang peralatan kimia dan fungsinya.

Hasil penelitian ini menunjukkan calon guru kimia tidak dapat mengidentifikasi peralatan laboratorium dan mengetahui fungsinya secara tepat. Kesalahan mahasiswa dapat diidentifikasi menjadi 5 kategori. Pertama, sebagian mahasiswa mengetahui nama dan fungsinya namun tidak mengetahui gambar alat (tidak mengetahui wujudnya). Kedua, mengetahui nama tetapi tidak mengetahui fungsi dan gambar alat. Ketiga, tidak dapat menyebutkan nama dengan benar tetapi mengetahui fungsi dan gambar alat. Keempat, mengetahui nama dan gambar tetapi tidak mengetahui fungsinya. Dan yang kelima, tidak mengetahui nama, fungsi maupun gambar alat. Pengetahuan mahasiswa yang kurang dapat dipengaruhi oleh jumlah peralatan dan bahan masih belum mancukupi, keterbatasan waktu praktikum dan perlunya proses pendampingan dari dosen pengampu praktikum.[]
\end{abstract}

Kata kunci: laboratorium, fungsi dan alat 


\section{PENDAHULUAN}

Pembelajaran kimia berkaitan erat dengan cara mencari tahu (inkuiri) tentang alam semesta secara sistematis, sehingga kimia bukan semata-mata hanya penguasaan kumpulan pengetahuan yang berupa fakta, konsep atau prinsip saja, tetapi juga merupakan suatu proses penemuan. Proses pembelajarannya menekankan pada pemberian pengalaman langsung melalui penggunaan dan pengembangan ketrampilan proses dan sikap ilmiah. ${ }^{1}$ Proses pembelajaran IPA harus membuat siswa memperoleh pengetahuan, ketuntasan keterampilan dan pengembangan sikap ilmiah dan nilai-nilai mulia dalam cara terintegrasi.

Proses pembelajaran tersebut dapat diperoleh melalui kegiatan laboratorium atau praktikum. Praktikum merupakan salah satu metode pembelajaran yang mampu menumbuhkembangkan rasa ingin tahu, aktif, kreatif, inovatif dan memiliki kejujuran dalam menghadapi suatu masalah dalam realita kehidupan. Melalui praktikum siswa memperoleh pengetahuan konkrit untuk melengkapi teori yang diperoleh di kelas yang bersifat verbalistik, melatih ketrampilan ilmiah, mananamkan dan menumbuhkan sikap ilmiah serta meningkatkan motivasi belajar siswa. Laboratorium dan berbagai sarana prasarananya berperan penting dalam proses pembelajaran Kimia. Pembelajaran kimia tanpa praktikum bagaikan melukis tanpa warna maupun kanvas. ${ }^{2}$

Dalam pelaksanaanya, penerapan praktikum dalam pendidikan sains memiliki banyak kendala. Disamping peralatan dan bahan yang kurang memadai, yang lebih penting dari hal tersebut adalah kurangnya kompetensi guru dalam praktikum. Peran guru dalam kegiatan pembelajaran terutama sains sangatlah penting. Dalam kegitan praktikum guru harus memenuhi

\footnotetext{
1 Depdiknas, 2003

${ }^{2}$ Zeynep Tatli and Alipasa Ayas, Virtual Laboratory Applications In Chemistry Education, Procedia Social and Behavioral Sciences, Vol. 9, hal. 938-942.,2010
} 
syarat/kompetensi untuk membangun pola pembelajaran berbasis praktikum. Kompetensi yang dimaksud diantaranya adalah penguasaan materi praktikum, pengelolaan kelas, pengetahuan tentang alat dan bahan dan lain-lain. Dalam pembelajaran berbasis praktikum guru berperan sebagai fasilitator, koordinator, pembimbing dan pengarah peserta didik agar terampil menggunakan alat, bekerja berdasarkan prosedur ilmiah sehingga keterampilan proses peserta didik dapat berkembang dengan baik. Namun realita di lapangan menunjukkan, banyak guru di Sekolah Menengah atau Madrasah Aliyah yang kurang memiliki kompetensi dalam bidang praktikum. Hal ini menyebabkan pelaksanaan pembelajaran kimia di sekolah tidak dilengkapi dengan praktikum.

Fakultas Ilmu Tarbiyah dan Keguruan (FITK) IAIN Walisongo merupakan salah satu Lembaga Penyelenggara Tenaga Kependidikan (LPTK) di Indonesia. Sejak tahun 2004, FITK telah membuka program studi Tadris Kimia yang akan mencetak calon-calon guru Kimia. Dalam proses perkulihan, disamping kompetensi keagamaan (diniyah) sebagai ciri khususnya, diajarkan pula kompetensi pedagogis (ilmu kependidikan) dan kompetensi profesional (ilmu Kimia). Kompetensi profesional disampaikan baik dengan teori maupun praktik. Praktikum yang dilaksanakan meliputi praktikum Kimia Dasar, Kimia Analitik, Kimia Organik, Kimia Anorganik, Kimia Fisik, Biokimia dan Kimia Makanan. Meskipun sudah melakukan banyak praktikum, namun kemampuan mahasiswa dalam praktikum masih relatif kurang. Hal ini dapat dilihat ketika pelaksanaan kegiatan praktikum dan nilai praktikum mahasiswa.

Deskripsi diatas mendorong perlunya dilakukan penelitian "Analisis Pengetahuan Calon Guru Kimia tentang Peralatan Laboratorium dan Fungsinya". Penelitian ini diharapkan mampu memberikan kontribusi dan evaluasi terhadap pelaksanaan praktikum di Laboratorium Kimia, FITK IAIN Walisongo Semarang. Evaluasi ini penting untuk menyiapkan calon guru kimia yang lebih baik dan layak ketika terjun ke dunia kerja. 


\section{METODE PENELITIAN}

Penelitian yang akan dilakukan merupakan penelitian kualitatif deskriptif .

\section{A. Subjek dan Objek Penelitian}

Subjek penelitian ini adalah mahasiswa Kimia Fakultas Tarbiyah IAIN Walisongo Semarang semester VI dan VIII Tahun Akademik 2011/2012 secara berturut-turut masing-masing berjumlah 29 dan 35 orang. Pemilihan subjek ini dengan pertimbangan bahwa mereka telah melaksanakan hampir sebagian besar praktikum. Disamping itu, mereka akan terjuan ke lapangan melalui Praktik Kerja Lapangan (PPL) dan bahkan hampir lulus kuliah. Objek penelitiannya adalah kompetensi mahasiswa dalam praktikum terutama pengetahuan mahasiswa tentang peralatan laboratorium dan fungsinya yang diukur dengan instrumen yang telah disiapkan.

B. Metode Pengumpulan Data

Data dikumpulkan melalui dokumentasi, observasi, pemberian tes dan angket. Dokumentasi dilakukan terhadap data-data sekunder seperti jumlah mahasiswa, inventarisasi peralatan laboratorium yang tersedia, dll. Observasi ini dilakukan guna memperoleh akses langsung terhadap obyek yang diteliti. Jadi observasi digunakan untuk melihat secara langsung proses praktikum yang dilaksanakan di Laboratorium Kimia, dan bagaimana kinerja mahasiwa. Tes dan angket digunakan untuk mengetahui pengetahuan mahasiswa tentang peralatan laboratorium dan fungsinya. Metode tes dlakukan dengan memberikan empat (4) jenis soal essai (open ended question) untuk mengetahui pemahaman siswa tentang perlatan laboratorium dan fungsinya secara lebih mendalam. Metode angket tertutup digunakan untuk mengungkapkan minat mahasiswa dalam praktikum, mengetahui keadaan laboratorium, waktu yang tersedia untuk praktikum, persiapan dan pelaksanaan praktikum serta laporan dan evaluasi praktikum. 


\section{Metode Analisis Data}

Analisa data merupakan proses terus menerus dengan pola keteraturan, penjelasan dan proporsisis. Analisa tes dibahas secara kualitatif. Adapun analisis yang digunakan pada data angket adalah analisis deskriptif kualitatif. Dalam hal ini digunakan rumus:

Nilai $=\frac{\text { Nilai Skor y ang Diperoleh }}{\text { Skor Maksimal }} \times 100 \%$

Indikator keberhasilan aktivitas peserta didik adalah sebagai berikut:

$$
\begin{aligned}
& <50 \%=\text { Kurang } \\
& 50-60 \%=\text { Cukup } \\
& 61-75 \%=\text { Baik } \\
& >75 \%=\text { Sangat Baik }
\end{aligned}
$$

Nilai skor ditentukan berdasarkan peringkat jawaban dengan mengacu pada skala likert seperti yang tertera pada Tabel 3.1 berikut:

Tabel 3.1 Peringkat Jawaban Menurut Skala Likert: ${ }^{3}$

\begin{tabular}{cc}
\hline Jawaban & Skor \\
\hline A & 4 \\
B & 3 \\
C & 2 \\
D & 1 \\
\hline
\end{tabular}

\footnotetext{
${ }^{3}$ Sugiyono, Metode Penelitian Pendidikan, Bandung: Alfabeta, 2007, hlm 135
} 


\section{HASIL PENELITIAN DAN PEMBAHASAN}

Laboratorium Kimia Fakultas Ilmu Tarbiyah dan Keguruan IAIN Walisongo saat ini menempati gedung baru yang merupakan Laboratorium Terpadu bersama laboratorium program studi Fisika, Biologi dan Matematika. Laboratorium kimia terbagi menjadi tiga ruang. Ruang 1 digunakan untuk praktikum Kimia Dasar, Kimia Anorganik dan Kimia Fisik. Ruang 2 digunakan untuk praktikum Kimia Organik, Biokimia dan Kimia Bahan Makanan. Sedangkan Ruang ketiga digunakan untuk praktikum Dasar Kimia Analitik dan Kimia pemisahan. Laboratorium Kimia tercatat hingga tahun 2012 memiliki kurang lebih 100 jenis alat laboratorium terdiri dari seperangkat alat gelas, alat berbahan kayu mapun plastik serta alat digital maupun konvensional.

\subsection{Hasil Penelitian}

Pertanyaan pertama yang diberikan kepada mahasiswa tentang peralatan laboratorium kimia dan fungsinya adalah mahasiswa diminta menuliskan peralatan laboratorium kimia yang ada dalam benak mahasiswa saat itu sebanyak-banyaknya. Hasilnya dapat dilihat pada Tabel 4.1 berikut:

Tabel 4.1. Hasil Analisa Jumlah Partisipan yang Menuliskan Peralatan Laboratorium untuk Angkatan 2009 dan 2010.

\begin{tabular}{llcc}
\hline & & \multicolumn{2}{c}{ Jumlah Partisipan } \\
\cline { 3 - 4 } No. & Nama Alat & $\begin{array}{c}\text { Angkatan } \\
\text { 2009 }\end{array}$ & $\begin{array}{c}\text { Angkatan } \\
\mathbf{2 0 1 0}\end{array}$ \\
\hline 1 & Buret & 23 & 28 \\
2 & Gelas Ukur & 21 & 29 \\
3 & Erlenmeyer & 27 & 34 \\
4 & Neraca & 15 & 10 \\
5 & Pipet tetes & 27 & 32 \\
6 & Pipet gondok & 22 & 27 \\
7 & Statif & 14 & 20 \\
8 & Labu ukur & 17 & 20 \\
9 & Tabung reaksi & 23 & 31
\end{tabular}




\begin{tabular}{|c|c|c|c|}
\hline 10 & Pengaduk & 9 & 24 \\
\hline 11 & Spatula & 11 & 1 \\
\hline 12 & Gelas beker & 21 & 27 \\
\hline 13 & Gelas arloji & 12 & 31 \\
\hline 14 & Cawan petri & 22 & 9 \\
\hline 15 & Cawan porselen & 12 & 22 \\
\hline 16 & Spektrofotometer & 4 & 1 \\
\hline 17 & Penangas & 4 & 20 \\
\hline 18 & Pipa kondensor & 2 & 12 \\
\hline 19 & Corong & 19 & 15 \\
\hline 20 & Corong pisah & 21 & 24 \\
\hline 21 & Oven & 9 & 5 \\
\hline 22 & Chamber & 4 & 7 \\
\hline 23 & Penjepit & 6 & 17 \\
\hline 21 & Penyangga kaki & 2 & 15 \\
\hline $\begin{array}{l}24 \\
25\end{array}$ & $\begin{array}{l}\text { tiga } \\
\text { Runcen }\end{array}$ & $\begin{array}{l}3 \\
5\end{array}$ & $\begin{array}{c}15 \\
4\end{array}$ \\
\hline $\begin{array}{l}25 \\
26\end{array}$ & $\begin{array}{l}\text { Bunsen } \\
\text { Peniepit kavu }\end{array}$ & 2 & 1 \\
\hline 27 & Termometer & 12 & 24 \\
\hline 28 & Pemanas spirtus & 1 & 6 \\
\hline 29 & Labu alas bulat & 2 & 5 \\
\hline 30 & Magnetik stirrer & 1 & 0 \\
\hline 31 & Hot plate & 1 & 1 \\
\hline 32 & Labu destilasi & 6 & 21 \\
\hline 33 & Plat tetes & 1 & 2 \\
\hline 34 & Buchner & 0 & 8 \\
\hline 35 & Rak tabung & 3 & 3 \\
\hline 36 & Pipet ukur & 0 & 1 \\
\hline
\end{tabular}

Pada pertanyaan pertama ini jawaban mahasiswa beragam. Untuk mahasiswa angkatan 2009 rata-rata jumlah alat yang disebutkan mahasiswa sebanyak 13 jenis alat sedangkan untuk angkatan 2010 sebanyak 15 jenis alat.

Pertanyaan kedua yaitu berdasarkan jawaban pertanyaan pertama, apakah mahasiswa mengetahui fungsi peralatan laboratorium yang sudah 
disebutkan pada soal nomor 1. Hasil jawaban mahasiswa dapat dirangkum dalam tabel 4.2 dan 4.3 berikut:

Tabel 4.2. Hasil Analisa Jawaban No.2 Peralatan Laboratorium dan Penjelasan Fungsinya untuk Angkatan 2009.

\begin{tabular}{|c|c|c|c|}
\hline \multirow[b]{2}{*}{ No. } & \multirow[b]{2}{*}{ Nama Alat } & \multicolumn{2}{|c|}{ Jumlah Partisipan } \\
\hline & & $\begin{array}{l}\text { Penjelasan } \\
\text { benar }\end{array}$ & $\begin{array}{c}\text { Penjelasan } \\
\text { salah/tidak } \\
\text { tahu }\end{array}$ \\
\hline 1 & Buret & 14 & 9 \\
\hline 2 & Gelas Ukur & 11 & 10 \\
\hline 3 & Erlenmeyer & 15 & 12 \\
\hline 4 & Neraca & 15 & - \\
\hline 5 & Pipet tetes & 24 & 3 \\
\hline 6 & Pipet gondok & 14 & 8 \\
\hline 7 & Statif & 7 & 7 \\
\hline 8 & Labu ukur & 8 & 9 \\
\hline 9 & Tabung reaksi & 18 & 5 \\
\hline 10 & Pengaduk & 9 & - \\
\hline 11 & Spatula & 10 & 1 \\
\hline 12 & Gelas beker & 14 & 7 \\
\hline 13 & Gelas arloji & 5 & 7 \\
\hline 14 & Cawan petri & 12 & 10 \\
\hline 15 & Cawan porselen & 7 & 5 \\
\hline 16 & Spektrofotometer & 1 & 3 \\
\hline 17 & Penangas & 4 & - \\
\hline 18 & Pipa kondensor & 2 & - \\
\hline 19 & Corong & 19 & - \\
\hline 20 & Corong pisah & 16 & 5 \\
\hline 21 & Oven & 8 & 1 \\
\hline 22 & Chamber & 2 & 1 \\
\hline 23 & Penjepit & 6 & - \\
\hline 24 & $\begin{array}{l}\text { Penyangga kaki } \\
\text { tiga }\end{array}$ & 3 & - \\
\hline 25 & Bunsen & 5 & - \\
\hline 26 & Penjepit kayu & 2 & \\
\hline 27 & Termometer & 11 & 1 \\
\hline 28 & Pemanas spirtus & 1 & - \\
\hline 29 & Labu alas bulat & 2 & - \\
\hline
\end{tabular}




\begin{tabular}{llll}
30 & Magnetik stirrer & 1 & - \\
31 & Hot plate & 1 & - \\
32 & Labu destilasi & 6 & - \\
33 & Plat tetes & 1 & - \\
34 & Buchner & 0 & 8 \\
35 & Rak tabung & 3 & 3 \\
36 & Pipet ukur & 0 & 1 \\
\hline
\end{tabular}

Tabel 4.3. Hasil Analisa Jawaban No.2 Perlatan Laboratorium dan Penjelasan Fungsinya untuk Angkatan 2010

\begin{tabular}{|c|c|c|c|}
\hline \multirow[b]{2}{*}{ No. } & \multirow[b]{2}{*}{ Nama Alat } & \multicolumn{2}{|c|}{ Jumlah Partisipan } \\
\hline & & $\begin{array}{l}\text { Penjelasan } \\
\text { benar }\end{array}$ & $\begin{array}{c}\text { Penjelasan } \\
\text { salah/tidak } \\
\text { tahu }\end{array}$ \\
\hline 1 & Buret & 22 & 13 \\
\hline 2 & Gelas Ukur & 14 & 15 \\
\hline 3 & Erlenmeyer & 18 & 16 \\
\hline 4 & Neraca & 10 & - \\
\hline 5 & Pipet tetes & 24 & 8 \\
\hline 6 & Pipet gondok & 17 & 10 \\
\hline 7 & Statif & 13 & 7 \\
\hline 8 & Labu ukur & 7 & 13 \\
\hline 9 & Tabung reaksi & 26 & 5 \\
\hline 10 & Pengaduk & 24 & - \\
\hline 11 & Spatula & 3 & 3 \\
\hline 12 & Gelas beker & 17 & 10 \\
\hline 13 & Gelas arloji & 23 & 8 \\
\hline 14 & Cawan petri & 6 & 4 \\
\hline 15 & Cawan porselen & 19 & 3 \\
\hline 16 & Spektrofotometer & - & \\
\hline 17 & Penangas & 20 & - \\
\hline 18 & Pipa kondensor & 12 & - \\
\hline 19 & Corong & 13 & 2 \\
\hline 20 & Corong pisah & 14 & 10 \\
\hline 21 & Oven & 5 & - \\
\hline 22 & Chamber & 1 & 6 \\
\hline 23 & Penjepit & 17 & - \\
\hline 24 & $\begin{array}{l}\text { Penyangga kaki } \\
\text { tiga }\end{array}$ & 15 & - \\
\hline 25 & Bunsen & 4 & - \\
\hline
\end{tabular}




\begin{tabular}{llcc}
\hline 26 & Penjepit kayu & 1 & - \\
27 & Termometer & 23 & 1 \\
28 & Pemanas spirtus & 6 & - \\
29 & Labu alas bulat & 5 & - \\
30 & Magnetik stirrer & 0 & - \\
31 & Hot plate & 1 & - \\
32 & Labu destilasi & 21 & - \\
33 & Plat tetes & 2 & - \\
34 & Buchner & 7 & 1 \\
35 & Rak tabung & 3 & - \\
36 & Pipet ukur & 1 & - \\
\hline
\end{tabular}

Petanyaan ketiga, mahasiswa diberikan tabel yang berisi delapan (8) nama peralatan yang ada di laboratorium kimia, kemudian mahasiswa diminta menuliskan fungsinya dan menggambarkan alat tersebut. Hasilnya terangkum pada Tabel 4.4. dan 4.5 berikut:

Tabel 4.4. Rekapitulasi Jawaban No 3 untuk Angkatan 2009

\begin{tabular}{llllll}
\hline \multirow{2}{*}{ No } & & \multicolumn{2}{c}{ Fungsi } & \multicolumn{2}{c}{ Gambar } \\
\cline { 2 - 5 } & & Benar & Salah & Benar & Salah \\
\hline 1 & Gelas kimia & 25 & 4 & 27 & 2 \\
2 & Labu leher tiga & 20 & 10 & 20 & 10 \\
3 & Pipet ukur & 15 & 14 & 9 & 21 \\
4 & Labu ukur & 24 & 5 & 25 & 4 \\
5 & Gelas ukur & 24 & 5 & 17 & 12 \\
6 & Erlenmeyer & 27 & 8 & 30 & 5 \\
7 & Adaptor & - & 29 & - & 29 \\
8 & Labu penyaring & - & 29 & - & 29 \\
\hline
\end{tabular}

Tabel 4.5. Rekapitulasi Jawaban No 3 untuk Angkatan 2010

\begin{tabular}{llllll}
\hline \multirow{2}{*}{ No } & & \multicolumn{2}{c}{ Fungsi } & \multicolumn{2}{c}{ Gambar } \\
\cline { 2 - 5 } & & Benar & Salah & Benar & Salah \\
\hline 1 & Gelas kimia & 33 & 2 & 33 & 2 \\
2 & Labu leher & 25 & 10 & 15 & 20 \\
& tiga & & & & \\
3 & Pipet ukur & 15 & 20 & 8 & 27 \\
4 & Labu ukur & 25 & 10 & 30 & 5 \\
5 & Gelas ukur & 30 & 5 & 33 & 2 \\
6 & Erlenmeyer & 30 & 5 & 33 & 2 \\
\hline
\end{tabular}




\begin{tabular}{llllll}
\hline 7 & Adaptor & 2 & 33 & 2 & 33 \\
8 & Labu & - & 35 & - & 35 \\
& penyaring & & & & \\
\hline
\end{tabular}

Pertanyaan keempat merupakan kebalikan dari pertanyaan sebelumnya. Pada kesempatan ini, mahasiswa diberikan delapan (8) gambar peralatan laboratorium, kemudian mahasiswa diminta menuliskan nama dan fungsi peralatan tersebut. Hasilnya dapat diamati pada tabel 4.6. dan 4.7 berikut:

Tabel 4.6. Rekapiltulasi Jawaban No 4 untuk Angkatan 2009

\begin{tabular}{llll}
\hline \multirow{2}{*}{ No } & Nama & \multicolumn{2}{c}{ Fungsi } \\
\cline { 3 - 4 } & & Benar & Salah \\
\hline 1 & Labu Alas Bulat & 12 & 17 \\
2 & Corong Buchner & 4 & 25 \\
3 & Pro Pipet & - & 29 \\
4 & Klem & 10 & 19 \\
5 & Corong Pisah & 29 & - \\
6 & Desikator & 17 & 12 \\
7 & Pipet Volume & 27 & 2 \\
8 & Gelas Arloji & 18 & 11 \\
\hline
\end{tabular}

Tabel 4.7. Rekapiltulasi Jawaban No 4 untuk Angkatan 2010

\begin{tabular}{llll}
\hline \multirow{2}{*}{ No } & Nama & \multicolumn{2}{c}{ Fungsi } \\
\cline { 3 - 4 } & & Benar & Salah \\
\hline 1 & Labu Alas Bulat & 33 & 2 \\
2 & Corong Buchner & 10 & 25 \\
3 & Pro Pipet & - & 35 \\
4 & Klem & 16 & 19 \\
5 & Corong Pisah & 30 & 5 \\
6 & Desikator & 19 & 16 \\
7 & Pipet Volume & 29 & 6 \\
8 & Gelas Arloji & 23 & 12 \\
\hline
\end{tabular}

Adapun hasil angket terhadap kegiatan laboratorium, keadaan laboratorium, waktu yang tersedia untuk praktikum, persiapan dan 
pelaksanaan praktikum, laporan dan evaluasi praktikum dapat dilihat apada Tabel 4.8 dan 4.9 berikut:

Tabel 4.8. Hasil Analisa angket angkatan 2009

\begin{tabular}{|r|l|r|r|r|r|r|r|r|r|}
\hline \multirow{2}{*}{ No. } & \multicolumn{4}{|c|}{ ASPEK } & \multicolumn{4}{|c|}{ Nilai } & \multicolumn{4}{c|}{ Pernyataan } & \multicolumn{4}{c|}{ Persentase (\%) } \\
\cline { 3 - 10 } & & $\mathbf{1}$ & $\mathbf{2}$ & $\mathbf{3}$ & $\mathbf{4}$ & $\mathbf{1}$ & $\mathbf{2}$ & $\mathbf{3}$ & $\mathbf{4}$ \\
\hline \multirow{2}{*}{1} & $\begin{array}{l}\text { Minat siswa terhadap } \\
\text { kegiatan laboratorium }\end{array}$ & 0 & 6 & 27 & 57 & 0 & 6,67 & 30 & 63,3 \\
\hline 2 & Keadaan laboratorium \\
\hline & 10 & 55 & 47 & 13 & 8 & 44 & 37,6 & 10,4 \\
\hline 3 & $\begin{array}{l}\text { Waktu pelaksanaan } \\
\text { praktikum }\end{array}$ & 20 & 46 & 14 & 10 & 22,2 & 51,1 & 15,6 & 11,1 \\
\hline 4 & $\begin{array}{l}\text { Persiapan dan } \\
\text { pelaksanaan }\end{array}$ & 16 & 34 & 27 & 49 & 12,7 & 27 & 21,4 & 38,9 \\
\hline 5 & Laporan dan evaluasi & 1 & 22 & 14 & 53 & 1,11 & 24,4 & 15,6 & 58,9 \\
\hline
\end{tabular}

Tabel 4.9. Hasil Analisa Angket angkatan 2010

\begin{tabular}{|c|l|r|r|r|r|r|r|r|r|}
\hline \multirow{2}{*}{ No. } & \multicolumn{1}{|c|}{ ASPEK } & \multicolumn{3}{|c|}{ Nilai Pernyataan } & \multicolumn{5}{c|}{ Persentase (\%) } \\
\cline { 3 - 10 } & $\mathbf{1}$ & $\mathbf{2}$ & $\mathbf{3}$ & $\mathbf{4}$ & $\mathbf{1}$ & $\mathbf{2}$ & $\mathbf{3}$ & $\mathbf{4}$ \\
\hline \multirow{2}{*}{1} & $\begin{array}{l}\text { Minat siswa terhadap } \\
\text { kegiatan laboratorium }\end{array}$ & 0 & 17 & 70 & 88 & 0 & 9,71 & 40 & 50,3 \\
\hline 2 & Keadaan laboratorium & 16 & 123 & 87 & 18 & 6,56 & 50,4 & 35,7 & 7,38 \\
\hline 3 & $\begin{array}{l}\text { Waktu pelaksanaan } \\
\text { praktikum }\end{array}$ & 21 & 116 & 26 & 12 & 12 & 66,3 & 14,9 & 6,86 \\
\hline & $\begin{array}{l}\text { Persiapan dan } \\
\text { pelaksanaan }\end{array}$ & 7 & 72 & 51 & 115 & 2,86 & 29,4 & 20,8 & 46,9 \\
\hline 5 & Laporan dan evaluasi & 2 & 24 & 50 & 97 & 1,16 & 13,9 & 28,9 & 56,1 \\
\hline
\end{tabular}

\subsection{Pembahasan}

\subsubsection{Analisa Pengetahuan Mahasiswa tentang Peralatan Kimia}

Pengetahuan tentang peralatan laboratorium dan fungsinya merupakan hal yang penting bagi seorang kimiawan. Berdasarkan tabel 4.1 dapat diketahui bahwa jumlah peralatan laboratorium kimia sebenarnya sudah cukup banyak. Mahasiwa angkatan 2009 rata-rata meyebutkan 13 jenis alat praktikum sedangkan mahasiswa angkatan 2010 menyebutkan rata-rata 15 
jenis alat. Erlenmeyer, tabung reaksi dan pipet tetes merupakan alat yang sangat familiar bagi mahasiswa. Dalam hal ini, ketika satu mahasiswa menyebutkan 20 alat, mahasiswa yang lain kadang hanya menyebutkan 15 alat atau bahkan menyebutkan 10 alat dan ketika salah satu mahasiswa menyebutkan gelas ukur maka yang lain menyebutkan labu ukur dan sebagainya. Hal ini menunjukaan bahwa pengetahuan mahasiswa sangat bervariasi. Dalam penelitian ini ditemukan beberapa kesalahan mahasiswa dalam meyebutkan nama peralatan kimia. Kesalahan yang pertama, ditemukan bahwa sebagian mahasiswa masih salah menyebutkan nama alat seperti alat BURET seringkali disebut BIURET padahal keduanya merupakan hal yang sangat berbeda. Buret merupakan alat kimia yang biasanya digunakan dalam titrasi yakni sebagai tempat larutan standar sekunder sedangkan BIURET merupakan salah satu larutan yang digunakan pada metode analisis kadar protein dalam suatu sampel. Kesalahan kedua yang disebutkan mahasiswa adalah beberapa mahasiswa seringkali tidak mengetahui bahwa satu alat kadangkala memiliki nama yang sama (sinonim) seperti GELAS KIMIA sama dengan GELAS BEKER dan PIPET GONDOK sama dengan PIPET VOLUME. Kesalahan ketiga, mahasiswa seringkali tidak bisa membedakan bererapa peralatan yang fungsinya hampir sama akan tetapi penggunaannya berbeda seperti LABU UKUR, GELAS UKUR, PIPET UKUR. Meskipun ketiganya dapat digunakan dapat digunakan untuk mengukur volume suatu zat, namun penggunaannya berbeda. Labu ukur memiliki beberapa ukuran volume yang biasa digunakan untuk pengenceran larutan, pembuatan larutan standar. Gelas Ukur juga memiluki beberapa ukuran volume, dan biasanya hanya digunakan untuk mengukur volume larutan sajan sedangkan pipet ukur memiliki rentang ukuran volume lebih kecil.

Pengetahuan mahasiswa tentang fungsi alat juga relatif cukup. Pada pertanyaan nomer 2, ketika mahasiswa diminta untuk menjelaskan fungsi peralatan laboratorium yang sudah mahasiswa sebutkan sendiri pada nomor 1, ternyata sebagian besar mahasiswa tidak mengetahui fungsinya. Ketika 
mahasiswa menyebutkan 15 jenis alat pada soal no 1, mereka hanya menyebutkan 10 jenis fungsi alat, sementara 5 yang lain tidak dijawab (no response). Di lain pihak, seringkali fungsi yang dijelaskan masih salah. Berdasarkan tabel 4.2 dan 4.3 dapat diketahui bahwa meskipun erlenmeyer merupakan alat yang cukup banyak disebut mahasiswa pada no 1, namun mereka mengalami kesulitan menjelaskan fungsinya secara tepat. Sebagain mahasiswa mnyebut bahwa erlenmeyer digunakan untuk mencampurkan sampel dengan bahan lain. Meskipun jawaban tersebut tidak sepenuhnya salah tetapi kurang tepat untuk erlenmeyer. Untuk mencampurkan alat dapat menggunakan beker glas atau tabung reaksi jika reaktannya cukup sedikit.

Analisa lebih lanjut tentang peralatan laboratorium dan fungsinya dapat dicermati pada tabel 4.4.dan 4.5 yang merupakan rekapitulasi jawaban soal nomor 3. Alat yang tidak diketahui mahasiswa angkatan 2009 dan 2010 sama sekali adalah labu penyaring. Hal ini kemungkinan karena mahasiswa belum pernah menggunakan alat ini ketika mereka praktikum. Alat lainya yang kurang familiar adalah adaptor. Mahasiswa angakatan 2010 hanya terdapat dua orang saja yang menjawab disertai fungsi dan gambar alat dengan benar, selebihnya tidak tahu meskipun meraka sudah pernah menggunakannya ketika praktikum destilasi. Untuk labu leher tiga, sebagian besar mahasiswa dapat menggambarkan alatnya namun tidak mengetahui fungsinya, sedangkan untuk pipet ukur mahasiswa sering menggambarkannya dengan pipet volume atau pipet gondok.

Hasil analisa pada pertanyaan 3 hampir sama dengan analisa pertanyaan ke 4. Ketika disajikan gambar alat dan mereka diminta menyebutkan nama dan fungsinya sebagian besar mahasiswa masih bingung dengan beberapa alat. Alat tersebut antara lain corong buchner, pro pipet, desikator/eksikator dan klem. Saat mahasiswa diberikan gambar corong buchner sering disebut sebagai labu penyaring karena bentuknya yang mirip dengan penyaring. Untuk pro pipet, mahasiswa sering menyebutkan hanya pipet (tetes). Meskipun fungsinya sama yaitu untuk mengambil sejumlah 
tertentu larutan namun pro pipet lebih teliti dibandingkan pipet (tetes) karena memiliki ukuran tertentu bahkan hingga $\mu \mathrm{L}$. Pada klem (clamp) sebagian besar mahasiswa tidak dapat menyebutkan dengan benar walaupun mereka sudah menyebutkan di soal nomor 1 dan menjelaskan fungsinya di soal nomor 2 dengan benar. Desikator /eksikator juga belum familiar bagi mahasiswa, dan meyebutnya sebagai kondensor. Untuk gelas arloji sebagian mahasiswa menyebutnya sebagai cawan petri.

Bedasarkan jawaban tentang peralatan laboratorium kimia dan fungsinya, dapat disarikan bahwa calon guru kimia tidak dapat mengidentifikasi peralatan laboratorium dan mengetahui fungsinya secara tepat. Hasil penelitian ini bersesuaian dengan hasil penemuan Bektas et al. ${ }^{4}$ (2011). Kesalahan mahasiswa dapat diidentifikasi menjadi 5 (lima) kategori. Pertama, sebagian mahasiswa mengetahui nama alat dan fungsinya namun tidak mengetahui gambar alat (tidak mengetahui wujud alatnya). Hal ini dapat dapat dicontohkan pada alat pipet ukur, desikator, gelas ukur, dan lainlain. Kedua, sebagian mahasiswa mengetahui nama alatnya akan tetapi tidak mengetahui fungsi dan gambar alatnya. Hal tersebut seperti alat gelas arloji, pro pipet dan lain sebagainya. Ketiga, sebagian mahasiswa tidak dapat menyebutkan nama alatnya dengan benar tetapi mengetahui fungsi dan gambar alat tersebut seperti buret, klem, cawan petri, kondensor, corong bucner dan lain-laian. Keempat, sebagian mahasiswa mengetahui nama alat dan gambarnya tetapi tidak mengetahui fungsinya. Hal ini paling banyak terjadi seperti pada labu destilasi, erlenmeyer, gelas ukur, labu ukur dan lain sebagainya. Dan yang kelima, sebagian mahasiswa tidak mengetahui nama alat, fungsi maupun gambar alat. Pada penelitian ini, alat tersebut antara lain adaptor dan labu penyaring.

\footnotetext{
${ }^{4}$ Bektas, O., Tuysuz, M., Kirbulut, Z.D., and Cetin-Dindar,A., 2011, Preservice Chemistry Teachers' Knowledge Regarding Laboratory Equipment and Their Functions, Procedia: Social and Behavioral Sciences 15 (2011) 5010-5014
} 


\subsubsection{Faktor-Faktor yang Mempengaruhi Pengetahuan tentang Peralatan Kimia}

Pengetahuan calon guru kimia yang masih relatif kurang tentang peralatan laboratorium dipengaruhi oleh beberapa faktor. Oleh karena itu untuk mengetahui faktor tersebut, salah satu metode pengumpulan data pada penelitian ini adalah dengan menggunakan angket tertutup. Data yang diperoleh dengan angket tertutup dianalisis secara deskriptif dan diperoleh prosentase yang hasilnya dapat dilihat pada Tabel 4.7. Angket mahasiswa ini terdiri dari 29 pertanyaan yang terbagi menjadi lima point penting yaitu minat terhadap kegiatan laboratorium, keadaan laboratorium, waktu pelaksanaan praktikum, persiapan dan pelaksanaan praktikum serta laporan dan evaluasi.

Informasi yang dapat diperoleh berdasarkan aspek minat mahasiswa terhadap praktikum kimia antara lain bahwa sebagian besar siswa setuju (dan sangat setuju) dengan kegiatan pemanfaatan laboratorium/ praktikum. Prosentase mahasiswa yang setuju mencapai 93\% untuk angkatan 2009 dan 90\% untuk angkatan 2010. Calon guru kimia ini merasa praktikum penting untuk dilaksanakan meskipun terkadang mahasiswa masih bingung ketika menghubungkan materi kuliah di kelas dengan materi praktikum.

Aspek yang kedua adalah keadaan laboratorium, yang berisi penilaian terhahap kondisi laboratorium, keadaan alat dan bahan, jumlah alat yang tersedia dan lain-lain. Pada penelitian ini, 56,9\% calon guru kimia menganggap bahwa kondisi laboratorium kimia masih kurang ideal. Satu ruang laboratorium digunakan untuk beberapa jenis praktikum meskipun waktu praktikumnya berbeda. Sebelum tahun 2012 ini, memang laboratorium kimia hanya ada satu ruang, dimana di laboratorium tersebut digunakan untuk seluruh praktikum kimia yang meliputi praktikum kimia dasar, kimia analitik, kimia fisika, kimia anorganik, kimia organik, biokimia dan bahan pangan. Namun saat ini kondisi laboratorium sudah lebih baik dibandingkan tahun-tahun sebelumnya. Meski demikian, sebagai besar 
mahasiswa berpendapat bahwa jumlah peralatan dan bahan masih belum mancukupi. Ditambah lagi, sebagian alat dalam kondisi rusak.

Faktor lain yang berpengaruh terhadap waktu pelaksanaan praktikum. Aspek ini berisi pertanyaan tentang jumlah praktikum dalam satu semester, lama praktikum, waktu tambahan praktikum ketika praktikum belum selesai dilaksanakan sesuai jadwal atau ada tidaknya waktu remidi praktikum. Pada program studi tadris kimia, jumlah praktikum dalam satu semester biasanya 2 jenis mata praktikum dengan jumlah SKS tiap praktikum adalah 2 SKS atau setara dengan $2 \times 90$ menit. Dengan alokasi waktu demikian, 26\% mahasiswa merasa cukup dan menyelesaikan praktikum tepat waktu dan sebagian besar (74\%) mahasiswa merasa masih kurang dan tidak dapat menyelesaikan tepat waktu. Permasalahan lain yang terjadi berkaitan dengan waktu praktikum adalah seringkali jadwal praktikum dan mata kuliah dilaksanakan di waktu yang beriringan, sehingga ketika praktikum belum selesai, mereka sudah harus masuk kelas untuk mengikuti perkuliahan. Idealnya alokasi waktu untuk praktikum lebih lama dibandingkan kuliah teori. Berdasarkan kondisi riil praktikum di laboratorium kimia IAIN Walisongo, apabila waktu praktikum tidak atau belum mencukupi maka boleh dilanjutkan di jam berikutnya apabila tidak ada perkuliahan atau dapat melanjutkan di jam istirahat selama ada laboran atau asisten praktikum yang bersedia mendampingi. Ditambah lagi apabila waktu praktikum dan kuliah teori berdekatan. Hal ini sejalan dengan Adisendjaja 5.

Pelaksaan praktikum dapat berjalan dengan baik apabila dilakukan persiapan yang matang. Oleh karena itu, faktor yang keempat yang mempengaruhi praktikum adalah persiapan dan pelaksanaan. Aspek persiapan meliputi persiapan alat dan bahan, pembuatan jurnal praktikum. Pada kenyaataanya mahasiswa tidak menyiapkan peralatan dan bahan sendiri, semua disiapkan oleh laboran dibantu oleh asisten laboratorium. Hampir semua mahasiswa membuat jurnal sebelum praktikum, akan tetapi

${ }^{5}$ Adisendjaja, Y. H., 2010, Pembelajaran Sains berbasis laboratorium 
seringkali mereka masih bingung dengan apa yang harus mereka kerjakan. Dalam pelaksanaan praktikum, berdasarkan hasil angket terdapat sebagian dosen yang menyampaikan pendahuluan (prolog) berupa penjelasan singkat tentang praktikum, cara kerja dan tujuan praktikum, tetapi ada sebagian dosen yang tidak memberikan pengarahan dahulu. Sejalan dengan hal tersebut, terdapat juga dosen yang membimbing dn mengawasi pelaksanaan praktikum, tetapi terdapat sedikit yang tidak melakukan hal tersebut.

Aspek kelima yang menjadi mempengaruhi pengetahuan mahasiswa tentang peralatan laboratorium dan fungsinya adalah laporan dan evaluasi praktikum. Berdasarkan analisa angket, semua mahasiswa membuat laporan praktikum secara individu setelah selesai melaksanakan praktikum. Laporan praktikum tersebut dikumpulkan, dan dikembalikan pada siswa. Diskusi/ pembahasan hasil praktikum tidak selalu dilaksanakan, hal ini dipengaruhi oleh keterbatasan waktu. Evaluasi praktikum meliputi tes pendahuluan (pre test), nilai kerja, laporan dan tes akhir (post test). Pre test dilakukan baik secara lisan maupun tertulis. Adapun post tes dilakukan dengan ujian praktek atau presentasi hasil praktikum. 


\section{KESIMPULAN}

Berdasarkan hasil penelitian dan pembahasan, maka dapat diambil beberapa kesimpulan yaitu Pengetahuan calon guru kimia tentang peralatan laboratorium dan fungsinya pada mahasiswa tadris kimia IAIN Walisongo Semarang relatif cukup dan perlu ditingkatkan. Adapun faktor yang mempengaruhi pengetahuan calon guru kimia tentang peralatan laboratorium dan fungsinya dapat dirangkum beberapa hal. Pengetahuan mahasiswa yang kurang dapat dipengaruhi oleh jumlah peralatan dan bahan masih belum mancukupi. Ditambah lagi, sebagian alat dalam kondisi rusak. Jumlah waktu yang terbatas juga merupakan salah satu kendala. Hal lain yang mempengaruhi berasal dari diri mahasiswa sendiri, mereka kurang terlibat aktif dalam penyiapan alat dan bahan, jurnal yang dibuat sebelum praktikum kurang mengatasi permasalahan mahasiswa ketika praktikum. Faktor yang lain adalah kurangnya peran dari dosen pengampu praktikum dam pengawasan dan bimbingan. Sistem evaluasi dan laporan praktikum juga masih kurang ideal dan pembahasan hasil diskusi perlu ditingkatkan. 


\section{DAFTAR PUSTAKA}

Bektas, O., Tuysuz, M., Kirbulut, Z.D., and Cetin-Dindar,A., 2011, Preservice Chemistry Teachers' Knowledge Regarding Laboratory Equipment and Their Functions, Procedia: Social and Behavioral Sciences 15 (2011) 5010-5014

Coburn, P., et al., Practical Guide to Computer in Education 2nd. California: Addison - Wesley Publication Company Inc, 1985

Depdiknas, Pedoman Khusus Pengembangan Silabus dan Sistem Penilaian Berbasis Kompetensi untuk Sekolah Menengah Atas, Jakarta: Dediknas, 2003

Dimyati dan Mudjiono, Belajar dan Pembelajaran, Jakarta: PT. Rineka Cipta, 2006.

Latuheru, Media Pembelajaran Dalam Proses Belajar Mengajar Masa Kini,Jakarta : Depdikbud, 1988

Ngalim Purwanto, Prinsip-Prinsip dan Teknik Evaluasi Pengajaran, Bandung : PT. Remaja Rosda Karya, 1997

Oemar hamalik, Kurikulum dan Pembelajaran, Jakarta: Bumi Aksara,2009

Purwanti Widhi H., Pembelajaran IPA (Kimia) Berbasis Laboratorium, Program Studi Pendidikan Kimia FMIPA Universitas Negeri Yogyakarta, email: dhe weedhy@yahoo.com

Sugiyono, Metode Penelitian Pendidikan, Bandung: Alfabeta, 2007, hlm 135

Suharsimi Arikunto, Prosedur Penelitian :Suatu pendekatan Praktik, Jakarta: Rineka Cipta, 2006

Tresna Sastrawijaya, Proses Belajar Mengajar Kimia, P2LPTK: Jakarta, 1998 
Yusuf Hilmi Adisendjaja, Kegiatan Praktikum dalam Pembelajaran Sains, Jurusan Pendidikan Biologi, Universitas Pendidikan Indonesia, diakses tanggal 1 Maret 2012

Zeynep Tatli and Alipasa Ayas, Virtual Laboratory Applications In Chemistry Education, Procedia Social and Behavioral Sciences, Vol. 9, hal. 938942.,2010 